ISSN: $1412-8837$

\title{
FAKTOR-FAKTOR YANG BERHUBUNGAN DENGAN PERILAKU IBU RUMAH TANGGA NELAYAN DALAM MENGGUNAKAN MEDIA MASSA SEBAGAI SUMBER INFORMASI
}

\author{
(Related Factors To Fisheries Housewife's Behavior In Using Mass Media As \\ Source Of Information)
}

\author{
M. Zulkarnain Yuliarso \\ Jurusan Sosial Ekonomi Pertanian \\ Fakultas Pertanian Universitas Bengkulu
}

\begin{abstract}
The research was aimed to 1) to research house wife's behavior in using mass media as information, 2) study of factors that related to house wife's behavior in using mass media. The data were collected in August 2009 at Pondok Besi dan Berkas. Sample number in this research were 40 people was taken by simple random method. In explaining the first purposes were use the descriptive analysis, and the second purpose was analyzed with Spearman Rank correlation test. The information which was gained from mass media especially the things related to entertainment, health, and religion could be helpful for daily life both for their personal and social life. The result of statistical analysis showed that the formal education, number of working hour, household income, their perception on information and attitude to living change, were apparently related to using mass media.

Key words: mass communication, house wife' behavior, fisherman
\end{abstract}

\section{PENDAHULUAN}

Informasi adalah sesuatu yang disampaikan kepada khalayak yang membutuhkan yang dapat berupa berita, kata, atau pengetahuan. Pengetahuan tersebut diperoleh dari investigasi dan studi. Informasi merupakan susunan fakta atau data yang disampaikan dari seseorang pada orang lain. Setiap orang mempunyai pola pemahaman yang berbeda terhadap suatu informasi. Informasi adalah segala sesuatu yang dapat membantu seseorang dalam mengorganisasikan segala aspek dari lingkungannya yang relevan yang sesuai dengan situasi dimana orang tersebut harus bertindak; informasi akan membantu dirinya dalam mengambil keputusan yang lebih mudah. Dengan demikian, informasi merupakan pengetahuan tertentu yang dipilih untuk memecahkan suatu masalah (Suryantini, 2004). 
ISSN: $1412-8837$

Informasi untuk setiap individu berbeda tergantung keterjangkauan terhadap sumber informasi, baik yang berasal dari media antar pribadi, media kelompok, media publik ataupun media massa (Cangara, 2000). Tingkat keterjangkauan terhadap berbagai sumber informasi akan menunjukan bagaimana tingkat kekosmopolitan, dimana ciri-ciri kekosmopolitan ini adalah kemampuan untuk berinteraksi dengan anggota-anggota diluar sistem sosialnya serta kemampuan untuk memanfaatkan media sebagai sarana untuk mengembangkan potensi diri (Mardikanto, 1991).

Tersedianya berbagai media sumber informasi, belum menjamin kemudahan dalam mengakses informasi. Hal ini tidak hanya dipengaruhi oleh kemampuan berinteraksi, kepemilikan sarana media sebagai penyedia informasi, tetapi juga kemampuan memiliki dan menerima informasi dari media yang ada. Pemilihan dan pemanfaatan sumber informasi akan berbeda-beda untuk setiap petani tergantung pada karakteristik individu dan kebutuhan informasi. Karakteristik tersebut dapat menunjukkan kemampuan seseorang untuk berkomunikasi, memilih media dan memanfaatkan informasi yang diperoleh.

Media massa dipandang memiliki kemampuan yang besar untuk menyebarkan pesan-pesan pembangunan kepada banyak orang yang tinggal di tempat terpisah dan menyebar secara serentak dan dengan kecepatan yang tinggi (Rogers et al dalam Jahi, 1988). Selanjutnya dijelaskan bahwa media massa dapat menyediakan informasi pada khalayak dan memotivasi mereka agar dapat mengadopsi inovasi pertanian, kesehatan, dan kesejahteraan keluarga serta semua hal yang terjadi diseluruh penjuru dunia Selain itu juga Anwar (2007)) menjelaskan bahwa penerimaan media massa sebagai alat informasi dan hiburan dapat mengubah pola hidup masyarakat lebih terbuka dan memabntu dalam merencanakan kehidupan. Karakteristik yang berbeda dipastikan akan membedakan keterjangkauan dan penggunaan media massa sebagai sumber informasi.

Tujuan dari penelitian ini adalah untuk: 1) Mengkaji perilaku ibu rumah tangga nelayan dalam menggunakan media massa sebagai sumber informasi, dan 2) mengkaji faktor-faktor yang berhubungan dengan perilaku tersebut.

74 | M. Zulkarnain Yuliarso. Faktor-Faktor yang Berhubungan dengan Perilaku Ibu 


\section{METODE PENELITIAN}

Penelitian ini dilakukan di Kelurahan Pondok Besi dan Kelurahan Berkas, Kota Bengkulu pada Bulan Agustus dengan total sample 40 orang ibu rumah tangga nelayang yang terpilih dengan menggunakan metode simple random sampling. Untuk menjawab tujuan penelitian dilakukan analisa deskriptif dan korelasi Rank Spearman.

\section{HASIL DAN PEMBAHASAN}

\section{Karakteristik Petani}

Rata-rata umur responden adalah 29.5 tahun dengan kisaran 22-44 tahun, dengan demikian semua responden termasuk kategori umur produktif. Dengan umur yang produktif, diharapkan dapat melakukan banyak hal yang dapat menjadikan dirinya sebagai manusia yang mampu berbuat banyak untuk keluarga dan masyarakat. Ditinjau dari tingkat pendidikan, rata-rata responden sudah mengecap pendidikan sampai lanjutan tingkat pertama atau sederajat (8 tahun) bahkan ada juga responden yang menyelesaikan pendidikan hingga SMU sederajat. Pendidikan non formal yang pernah diikuti oleh sebagian besar responden adalah adalah penyuluhan kesehatan dan sosialisasi program pemberdayaan dari pemerintah. Dengan tingkat pendidikan yang sedemikian rupa, diharapkan petani dapat memanfaatkan pengetahuan yang mereka miliki dan lebih terbuka terhadap perubahan-perubahan baru sehingga dapat mengembangkan potensi diri.

Dengan alasan ekonomi, semua responden memutuskan untuk bekerja membantu suami dalam mencari nafkah membantu memenuhi kebutuhan keluarga dengan berdagang. Rata-rata alokasi waktu kerja responden adalah sebesar 4.5 jam/hari, dengan kisaran sebanyak 3-6 jam/hari. Alokasi waktu kerja yang bervariasi ini akan mempengaruhi alokasi waktu mereka dalam menikmati mediamedia yang ada.

Rata-rata penghasilan rumah tangga sebesar Rp 650.000,-/bulan dengan kisaran penghasilan Rp 250.000,- - Rp 1.100.000.-/bulan. Jumlah tanggungan responden rata-rata 2 orang dengan kisaran 1-4 orang setiap respondennya. Ratarata jumlah anak yang bersekolah sebanyak 2 orang. Banyak sedikitnya anak yang bersekolah akan menuntut ibu-ibu untuk mempunyai wawasan yang lebih baik, karena mereka terkadang harus mendampingi anak-anak mereka dalam belajar dan mengerjakan tugas-tugas dari sekolah. 
ISSN: $1412-8837$

Persepsi yang baik terhadap pentingnya informasi dalam kehidupan, akan membuat seseorang menjadi lebih respon terhadap keberadaan sumber informasi baik sumber informal personal maupun yang berasal dari media massa, karena semakin dekat ia dengan sumber informasi akan membuat mereka mempunyai kesempatan untuk mendapatkan banyak hal yang bermanfaat. Sebagian besar responden (95\%) mempunyai persepsi yang baik terhadap informasi, mereka menilai bahwa informasi sangat penting dalam kehidupan karena dapat meningkatkan pengetahuan yang dimanfaatkan dalam kehidupan sehari-hari. Media massa dinyatakan responden sebagai media yang mampu menyampaikan banyak ragam informasi yang dibutuhkan oleh mereka. Persepsi yang baik terhadap informasi dari media didukung juga oleh sikap yang terbuka dan optimistik terhadap perubahan. Sebagian besar responden (95\%) menyatakan bahwa seorang wanita harus dapat menjalankan peran dan fungsi mereka baik sebagai individu, istri, ataupun ibu dari anak-anak mereka. Untuk dapat berperan lebih baik harus mempunyai banyak pengetahuan yang dapat mereka peroleh secara non formal. Salah satunya adalah dengan menterdedahkan diri dengan media massa, karena fungsi media massa adalah dapat mengatasi rendahnya pendidikan formal dalam peningkatan pengetahuan, kesadaran dan perubahan perilaku (Kuswita, 2001).

\section{Perilaku Ibu Rumah Tangga Nelayan dalam Menggunakan Media Massa sebagai Sumber Informasi}

Media massa dapat memotivasi dan menggerakan masyarakat untuk lebih terbuka, inovatif dan mampu berpartisipasi dalam pembanguan. Agar partisipasi khalayak pedesaan menjadi lebih bermakna, media massa dituntut untuk mampu memberikan informasi dan pengetahuan-pengetahuan baru kepada masyarakat. Selain itu juga kemudahan mengakses dan memanfaatkan media massa sebagai sumber informasi yang tersedia merupakan hal yang sangat mendasar. Media Massa yang dinikmati oleh ibu rumah tangga nelayan adalah Televisi, radio, koran dan tabloid.

Televisi dapat dikatakan sebagai media yang paling banyak dimiliki oleh masyarakat, hal ini tidak terlepas dari karakteristik yang melekat pada televisi sebagai media yang mampu menyatukan antara fungsi audio dan visual sehingga dapat memperjelas dan mendekatkan dunia yang jauh ke depan mata tanpa perlu

76 | M. Zulkarnain Yuliarso. Faktor-Faktor yang Berhubungan dengan Perilaku Ibu 
menyediakan waktu dan biaya khusus (Cangara, 2000). Keberadaan stasiun-stasiun televisi saat ini memberikan kemudahan dan pilihan bagi masyarakat secara leluasa untuk menentukan saluran mana yang mereka senangi. Di sini responden hanya diminta menjawab frekuensi menonton televisi tanpa mempersoalkan jaringan stasiun mana yang mereka pilih. Semua responden $(100 \%)$ mengaku menonton televisi tiap harinya dengan rata-rata jam menonton di atas 3,4 jam per harinya, artinya di televisi selalu saja ada acara yang menarik untuk ditonton.

Semua responden (100\%) menyatakan bahwa acara yang paling menarik dan paling sering ditonton adalah hiburan, seperti sinetron, film, reality show dan infotainment bila dibandingkan dengan jenis acara lainnya. Secara umum, televisi dipandang sebagai media yang selalu memberikan informasi yang selalu menarik dan mudah untuk diikuti bila dibandingkan dengan jenis media yang lain, meskipun sebagian besar responden (90\%) menyatakan bahwa informasi tersebut tidak selalu baru atau kadang hanya mengulang dari apa yang sudah ada sebelumnya. Hanya acara berita yang selalu memberikan informasi terbaru bagi mereka sebagai penikmat televisi.

Tetapi, dengan menonton televisi mereka merasakan pengetahuan mereka dapat bertambah. Informasi-informasi yang disiarkan melalui televisi, khususnya informasi yang berkaitan dengan pengaturan rumah rumah tangga, keagamaan (religi) dan kesehatan cukup membantu meningkatkan pengetahuan yang sangat berguna dalam kehidupan sehari-hari, tidak hanya bagi mereka sendiri tetapi juga dapat dibagi dengan sesama tetangga sekitar mereka.

Sebanyak 60\% responden menyatakan bahwa dalam satu bulan terakhir mereka menikmati siaran radio. Rata-rata frekuensi mendengarkan radio adalah 3 hari per minggu dengan durasi rata-rata 2 jam per harinya. Siaran yang paling sering mereka dengar adalah siaran hiburan dari stasiun pemancar swasta, bila dibandingkan dengan siaran berita atau sejenisnya. Waktu mendengarkan radio juga lebih banyak dilakukan di warung, atau tempat berjualan sambil menunggu pembeli sehingga waktu yang mereka curahkan untuk mendengarkan radio juga sangat tergantung dari lama tidaknya mereka jualan. Karena jadwal mendengarkan radio dilakukan pada saat bekerja dan sifatnya hanya sebagai hiburan, maka otomatis tidak banyak atau bahkan tidak ada informasi penting yang dapat mereka tangkap dengan jelas. Artinya, radio tidak memberikan dampak khusus terhadap perubahan pengetahuan yang dimiliki oleh mereka. 
ISSN: $1412-8837$

Hanya $42 \%$ responden yang secara rutin membaca dan mengikuti perkembangan berita dari koran dalam satu bulan terakhir, sedangkan tabloid, hanya $12 \%$ responden yang rutin membacanya. Kelebihan media cetak yang mampu memberi informasi lebih lengkap, bisa dibawa kemana-mana, terdokumentasi dan mudah dinikmati secara berulang (Cangara, 2000), ternyata tidak dapat menjadikan media jenis ini sebagai media yang paling dinikmati di tengah masyarakat.

Faktor yang mendukung mereka dapat secara rutin menikmati koran/tabloid adalah karena domisili dan aktivitas mereka berada di kawasan kota, sehingga untuk mengakses dan membeli koran/tabloid sangatlah mudah. Sedangkan mereka yang tidak dapat menikmati koran/tabloid karena waktu mereka dalam sehari-hari dihabiskan untuk berjualan atau mambantu suami dan mengurusi rumah tangga. Selain itu juga faktor ekonomi merupakan faktor yang sangat membatasi mereka dalam menyediakan fasilitas tersebut di rumah. Pemenuhan kebutuhan dasar rumah tangga dan untuk keperluan anak sekolah mereka anggap lebih utama bila dibandingkan untuk membeli koran/tabloid.

Dalam tingkatan perilaku penggunaan media massa dapat terlihat bahwa, media massa baik cetak ataupun elektronik sudah merupakan kebutuhan hidup harian dengan tujuan penggunaan cukup jelas, sebagai sumber hiburan dan informasi. Untuk kedua tujuan ini, ternyata televisi diterima sebagai sumber yang lebih populer dari jenis media apapun dan dapat diandalkan oleh banyak orang.

Meskipun demikian, semua responden menyatakan bahwa perilaku keseharian tidak hanya disebabkan sebagai efek langsung dari media tetapi juga sebagai akibat dari interaksi yang terjadi di masyarakat yang sudah terlebih dahulu mendapatkan informasi dari berbagai sumber termasuk media massa. Sehingga dapat dikatakan bahwa media massa dapat berperan secara langsung ataupun tidak langsung terhadap kekayaan informasi yang dimiliki oleh ibu rumah tangga, yang nantinya dapat mempengaruhi perilaku dalam kehidupan sehari-hari.

\section{Faktor-faktor yang Berhubungan dengan Perilaku Menggunakan Media Massa Sebagai Sumber Informasi}

Untuk melihat hubungan antara pendidikan formal, alokasi jam kerja di luar pekerjaan rumah tangga, penghasilan rumah tangga, persepsi terhadap informasi, dan persepsi terhadap keberdayaan perempuan dengan Perilaku menggunakan

78 | M. Zulkarnain Yuliarso. Faktor-Faktor yang Berhubungan dengan Perilaku Ibu 
media massa, digunakan uji Rank-Spearman. Hasil analisis tersebut diuraikan sebagai berikut.

Variabel pendidikan formal berhubungan signifikan dengan perilaku memanfaatkan media massa pada taraf kepercayaan $95 \%$ dengan nilai rs $=0.621$ Artinya, semakin tinggi pendidikan, maka pemanfaatan media massa juga akan tinggi.

Berhubungan nyatanya pendidikan formal dengan perilaku penggunaan media massa adalah sesuatu yang sangat erat karena menggunakan tidak hanya berarti mampu menikmati media massa, tetapi juga mampu menyerap dan memanfaatkan media massa sebagai sumber informasi yang bermanfaat bagi kehidupan sehari-hari. Orang yang tingkat pendidikan formalnya tinggi akan sangat terbuka terhadap sesuatu yang baru, lebih mudah untuk menerima, memilih dan mencerna informasi yang bermanfaat untuk memperkaya pengetahuan dan kemampuan sehingga dapat membuat keputusan yang akan memberikan keuntungan tidak hanya bagi diri mereka sendiri, tetapi juga bagi keluarga dan masyarakat yang lebih luas. Hal ini sejalan dengan apa yang dinyatakan Slamet sebagaimana dikutip oleh Yuliarso (2005) bahwa tingkat pendidikan seseorang mempengaruhi tingkat pemahaman terhadap apa yang dipelajari.

Alokasi Jam Kerja di Luar Pekerjaan Rumah Tangga berhubungan nyata negatif pada taraf kepercayaan $95 \%$ dengan nilai $r s=-0.522$. Artinya ada korelasi negatif antara variabel ini dimana semakin banyak jam kerja di luar rumah berarti waktu yang akan dicurahkan untuk menikmati media massa akan berkurang.

Berhubungan nyata variabel ini karena mengingat media yang umum dimiliki dan sering dinikmati adalah televisi, yang untuk menikmatinya membutuhkan waktu khusus di rumah, karena tidak seperti radio atau surat kabar, televisi tidak memungkinkan untuk selalu dibawa termasuk ketika mereka harus bekerja. Apabila waktu mereka lebih banyak dihabiskan di luar rumah untuk bekerja, maka waktu untuk menikmati media televisi ini juga akan berkurang.

Penghasilan rumah tangga berpengaruh nyata dengan tingkat penggunaan media massa pada taraf kepercayaan $95 \%$. Dengan nilai $r s=0.630$, menunjukan bahwa semakin tinggi penghasilan rumah tangga pedesaan maka penggunaan media massa juga akan semakin tinggi. Pemenuhan fasilitas kehidupan termasuk media massa membutuhkan biaya, sehingga mereka yang mempunyai penghasilan tinggi dapat memenuhi dan menyediakan fasilitas media yang dibutuhkan, karena 
ISSN: $1412-8837$

fasilitas-fasilitas tersebut hanya dapat terpenuhi jika rumah tangga mampu menyediakan atau menyisihkan sebagian penghasilan mereka untuk memenuhinya. Hal ini sesuai dengan apa yang dinyatakan oleh Pusposutardjo (2001) bahwa tingkat pendapatan akan sangat membantu dalam mendapatkan informasi dari media massa yang jelas penggunaannya akan sangat membutuhkan biaya. Hal ini berarti, jika rumah tangga mampu menyediakan fasilitas media massa maka anggota rumah tangga termasuk istri akan dapat mengakses media tersebut yang menyediakan berbagai macam informasi yang dapat meningkatkan pengetahuan mereka.

Persepsi terhadap informasi berhubungan nyata dengan keterjangkauan terhadap media massa pada taraf kepercayaan $95 \%$. Dengan nilai $\mathrm{rs}=0.690$ menunjukan bahwa semakin baik persepsi terhadap informasi, maka mereka akan mempunyai tingkat keterjangkauan yang tinggi terhadap media massa. Hasil penelitian ini sejalan dengan penelitian Weldyansyah (2007) yang menyatakan bahwa persepsi yang baik terhadap informasi berhubungan nyata dengan keterjangkauan petani KP2A terhadap media massa.

Persepsi yang baik terhadap informasi diyakini akan membantu semangat perubahan menuju kearah yang lebih baik, ibu-ibu rumah tangga akan meningkatkan akses terhadap media massa tidak hanya sebagai penikmat tetapi juga mampu memilih dan mencerna informasi yang diterima sehingga dapat memperbaiki pengetahuan sikap dan ketrampilan mereka dalam banyak hal yang akan bermanfaat tidak hanya untuk diri mereka beserta keluarganya tetapi juga untuk masyarakat yang lebih luas.

Persepsi terhadap keberdayaan perempuan berhubungan nyata dengan penggunaa media massa pada taraf $95 \%$. Dengan nilai rs $=` 0.543$ menunjukkan bahwa semakin tinggi persepsi terhadap keberdayaan perempuan maka semakin tinggi pula tingkat keterjangkauan mereka terhadap media massa. Persepsi terhadap keberdayaan perempuan merupakan pandangan perempuan terhadap kemampuan dan kemandirian dimana kaum perempuan harus dapat menjalankan peran dan fungsi mereka baik sebagai individu, istri ataupun ibu dari anak-anak mereka. Untuk dapat berperan lebih baik harus mempunyai banyak pengetahuan yang dapat mereka peroleh secara non formal. Salah satunya adalah dengan menterdedahkan diri dengan media massa, karena salah satu fungsi media massa adalah dapat mengatasi rendahnya pendidikan formal dalam peningkatan 
pengetahuan, kesadaran dan perubahan perilaku sehingga dapat berpartisipasi menciptakan kehidupan yang lebih baik.

\section{SIMPULAN DAN SARAN}

Berdasarkan hasil penelitian dan pembahasan dapat dikemukakan simpulan sebagai berikut. 1). Dalam tingkatan perilaku penggunaan media massa dapat terlihat bahwa media massa baik cetak ataupun elektronik sudah merupakan kebutuhan hidup harian dengan tujuan penggunaan cukup jelas, sebagai sumber hiburan dan informasi. Untuk kedua tujuan ini, ternyata televisi diterima sebagai sumber yang lebih populer dari jenis media apapun dan dapat diandalkan oleh banyak orang. 2) Pendidikan formal, jumlah jam kerja di luar rumah, penghasilan rumah tangga, persepsi terhadap informasi dan persepsi terhadap keberdayaan perempuan berhubungan nyata dengan perilaku penggunaan media massa sebagai sumber informasi oleh ibu rumah tangga nelayan.

Saran yang dapat diberikan adalah perlu adanya pendidikan penyuluhan (sosialisasi) mengenai pentingnya menterdedahkan atau menjangkau media, dalam artian tidak hanya menikmati apa yang disampaikan oleh media tersebut, tetapi juga dapat mencerna, menyerap informasi dan memanfaatkan media massa sebagai sumber informasi yang dapat dijadikan panduan dalam menjalankan kehidupan agar kaum perempuan dapat menjadi figur yang mampu mengembangkan diri sesuai potensinya, mampu membangun keluarga yang bahagia dan sejahtera, serta dapat bermanfaat bagi masyarakat yang lebih luas.

\section{DAFTAR PUSTAKA}

Anwar. 2007. Manajemen Pemberdayaan Perempuan (Perubahan Sosial Melalui Pembelajaran Vocational Skill Pada Keluarga Nelayan). Bandung, CV. Alphabeta.

Cangara, Hafied. 2000. Pengantar Ilmu Komunikasi. Jakarta, PT. Radjawali Pers.

Jahi, Amri. 1988. Media Massa dan Pembangunan Pedesaan di Negara-Negara Dunia Ketiga dalam Komunikasi Massa dan Pembangunan Pedesaan di NegaraNegara Dunia Ketiga. Disunting oleh Amri Jahi. Jakarta, PT. Gramedia.

Kuswita, W. 2001. Komunikasi Massa: Sebuah Analisi Media Televisi. Jakarta, Rineka Cipta.

Mardikanto, T. 1991. Penyuluhan Pembangunan Pertanian. Surakarta, UNS Press. 
ISSN: $1412-8837$

Suryantini, H. 2004. Pemanfaatan Informasi Teknologi Pertanian Oleh Penyuluh. Pertanian, (Kasus di Kabupaten Bogor, Jawa Barat). Jurnal Pusat Perpustakaan dan Penyebaran Teknologi Pertanian. Hal 15-21. Bogor.

Weldyansyah. 2007. Keterjangkauan Petani Terhadap Media Informasi (Studi Pada Anggota Petani Pemakai Air KP2A Kecamatan Seginim Kabupaten Bengkulu Selatan). Skripsi. Jurusan Sosial Ekonomi Pertanian. Universitas Bengkulu. Tidak dipublikasikan.

Yuliarso, M.Z. 2005. Partisipasi Petani dalam Kelompok Tani (Studi pada Kelompok Tani Tambak Ikan Air Tawar "Mitra Tani" Desa Petir, Kecamatan Dramaga, Kabupaten Bogor). Jurnal Agrisep Vol 3 No. 2, Maret 2005: 101- 106. Bengkulu.

82 M. Zulkarnain Yuliarso. Faktor-Faktor yang Berhubungan dengan Perilaku Ibu 